Review

\title{
Realizing Beneficial End Uses from Abandoned Pit Lakes
}

\author{
Cherie D. McCullough ${ }^{1, *(\mathbb{D}}$, Martin Schultze $\left.{ }^{2} \mathbb{(}\right)$ and Jerry Vandenberg ${ }^{3}$ \\ 1 Mine Lakes Consulting, Perth 6027, Australia \\ 2 UFZ-Helmhotz-Centre for Environmental Research, 39114 Magdeburg, Germany; martin.schultze@ufz.de \\ 3 Vandenberg Water Science, Kelowna, BC V1P 1H9, Canada; jerry@vws.ltd \\ * Correspondence: cmccullough@minelakes.com
}

Received: 20 December 2019; Accepted: 30 January 2020; Published: 2 February 2020

\begin{abstract}
Pit lakes can represent significant liabilities at mine closure. However, depending upon certain characteristics of which water quality is key, pit lakes often also present opportunities to provide significant regional benefit and address residual closure risks of both their own and overall project closure and even offset the environmental costs of mining by creating new end uses. These opportunities are widely dependent on water quality, slope stability, and safety issues. Unfortunately, many pit lakes have continued to be abandoned without repurposing for an end use. We reviewed published pit lake repurposing case studies of abandoned mine pit lakes. Beneficial end use type and outcome varied depending upon climate and commodity, but equally important were social and political dynamics that manifest as mining company commitments or regulatory requirements. Many end uses have been realized: passive and active recreation, nature conservation, fishery and aquaculture, drinking and industrial water storage, greenhouse carbon fixation, flood protection and waterway remediation, disposal of mine and other waste, mine water treatment and containment, and education and research. Common attributes and reasons that led to successful repurposing of abandoned pit lakes as beneficial end uses are discussed. Recommendations are given for all stages of mine closure planning to prevent pit lake abandonment and to achieve successful pit lake closure with beneficial end uses.
\end{abstract}

Keywords: mine lake; pit lake; closure; planning; repurposing; end use; water quality

\section{Introduction}

Mine pit lakes are created, intentionally or otherwise, when open cut mine voids fill with water after mining and dewatering cease [1]. When voids extend below regional groundwater levels, groundwater inflows may be the dominant contribution and controls to final lake volume and depth, respectively [2,3]. Where surface water flows are significant into and/or out of the pit lake, this water source may be more important in controlling pit lake hydrology and quality $[4,5]$.

There is growing recognition that pit lakes can represent significant liabilities at mine closure, particularly to the environment [6]. With over a half century of open cut mining demonstrated in most countries, pit lake legacies have been shown to present long-term and significant health, safety, and environmental risks that are difficult to resolve [7]. These risks are, in particular, poor water quality (elevated metal concentrations and/or acidification due to the mobilization of metals as contaminants of potential concern (COPC) and the oxidation of sulfide minerals, particularly pyrite) $[6,8,9]$, unstable sidewalls and, thus, landslides $[10,11]$, and steep sidewalls accompanied by the risk of falling and drowning $[12,13]$. These risks can typically be mitigated by closure planning and associated technical measures during mining and closure or following relinquishment $[7,10,11,14]$. 
However, pit lakes are one of the few closure landforms that concurrently present opportunities to address residual closure risks of both their own and overall project closure $[15,16]$. The following end uses have been realized: passive and active recreation, nature conservation, fishery and aquaculture, drinking and industrial water storage, greenhouse carbon fixation, flood protection and waterway remediation, disposal of mine and other waste, mine water treatment and containment, and education and research [13].

Determining end-use values is a first stage in assessing opportunities posed by a pit lake and the extent of works and ongoing management that may be required to achieve this opportunity [17]. A clear definition of intended end-use values during closure planning (even at approval stages) can direct operational activities and closure works toward reliably achieving these values.

Typically, values fall within three types (Figure 1):

1. Wildlife;

2. Recreation; and,

3. Primary production.
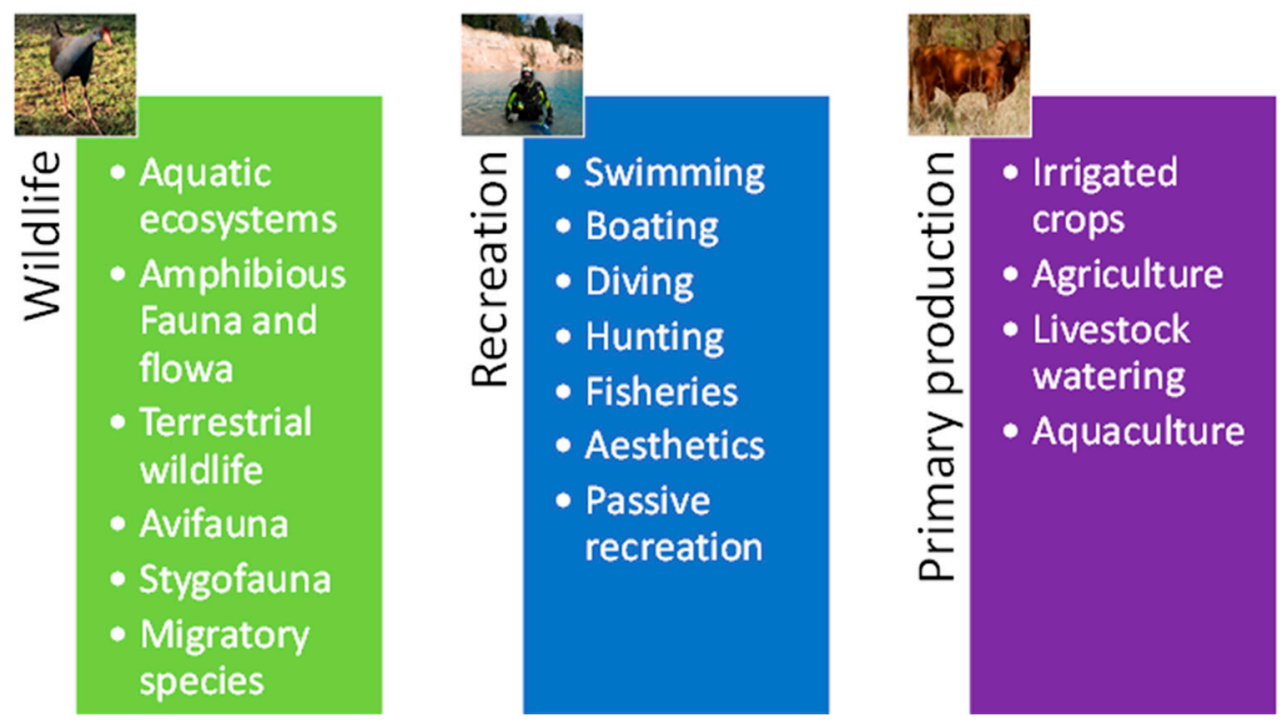

Figure 1. Key end-use value definitions for pit lakes.

This approach allows flexibility in applying closure objectives and criteria to be based on the geochemical, geotechnical, and social/environmental baseline conditions relevant to a particular mine site.

In this paper, we provide examples of existing pit lake end uses and some collective insights from our work across three continents and internationally as to what end uses have been successful and why.

\section{Approach}

This review used the Mine Lakes Consulting pit lake database as a primary source. This digital database reviews publicly available, e.g., online and published documents, that relate to pit lakes, including their physical, chemical, biological, and socio-economic characteristics, with an emphasis on the repurposing of abandoned or planned pit voids for beneficial end uses. Data on physico-chemical characteristics (morphology and water chemistry) along with biological and social attributes, history, and development are collected. Metadata, such as references and other data sources, are also noted. This database was established in 2004 and is updated with keyword alerts on Google Scholar and ResearchGate and from regular review of other key, peer-reviewed pit lake publication sources, 
including industry and academic conferences, e.g., Mine Closure and International Mine Water Association congress proceedings.

We reviewed 247 published articles, book chapters and unpublished industry studies combined with our own collective and international experiences for a range of abandoned pit lakes, their key attributes and the success of their outcomes.

As previous studies have found [15,18], most pit lakes are located in Australasia, Europe, and North America. Although the higher number of pit lakes in these continents is, to some extent, an artifact of the authors' locations and native languages in addition to where most publishing activity has occurred, we focused on lakes from these continents where there was a greater knowledge base (Table 1). Within this dataset, most pit lake lakes were in Canada (45), the USA (29), the Czech Republic (26), and Australia and Germany (24 lakes each).

Table 1. Pit lakes with defined pit lake end uses $(n>1)$.

\begin{tabular}{ccccccc}
\hline Country & Wildlife & Fishery & Recreation & Source & Waste & Total \\
\hline Australia & 7 & 6 & 8 & 2 & 2 & 25 \\
Canada & 6 & 22 & 2 & & 5 & 35 \\
Czech Republic & 11 & 7 & 18 & 11 & 3 & 50 \\
Germany & 2 & 2 & 10 & 0 & 2 & 16 \\
New Zealand & 2 & 0 & 1 & 0 & 0 & 3 \\
Poland & 13 & 5 & 0 & 0 & 1 & 19 \\
Spain & 0 & 0 & 1 & 0 & 2 & 3 \\
USA & 9 & 10 & 1 & 2 & 0 & 22 \\
Total & 50 & 52 & 41 & 15 & 15 & \\
\hline
\end{tabular}

\section{Realized End Uses}

Our review identified a number of end uses that have been realized in abandoned pit lakes. Most end uses were defined as follows:

- Wildlife: providing a significant wildlife habitat for aquatic and/or amphibious ecology;

- Fishery: used as either an incidental, planned, or stocked fishery or for the purposes of aquaculture-fin fish, crustacea, or otherwise;

- Recreation: used for active recreation, such as swimming, boating, water skiing, and self-contained underwater breathing apparatus (SCUBA) diving, and also including passive recreation of water-oriented amenities, such as picnic areas and walking/biking trails around the lake;

- Source and storage of water: providing a water source for either potable, irrigation (agriculture or horticulture), or industrial purposes and storage space for regional water management, including flood protection;

- Waste storage and treatment: used as a waste storage receptacle for either mine wastes or unrelated wastes, such as from nearby industries.

Examples of successful realization of these end uses are demonstrated by the following case studies.

\subsection{Wildlife}

Steep sides and poor sediment development can limit wildlife by limiting aquatic macrophyte growth rate and extent [19] and macroinvertebrate community abundance and diversity [20,21]. Conversely, the steep-sided pit walls above the water surface can provide a valuable habitat for species that are adapted to such conditions, such as bighorn sheep Ovis canadensis around Sphinx Pit Lake (Figure 2). In British Columbia, Canada, Mountain Goats Oreamnos americanus can be found seeking refuge on the benches of abandoned mine pits [22-37]. 

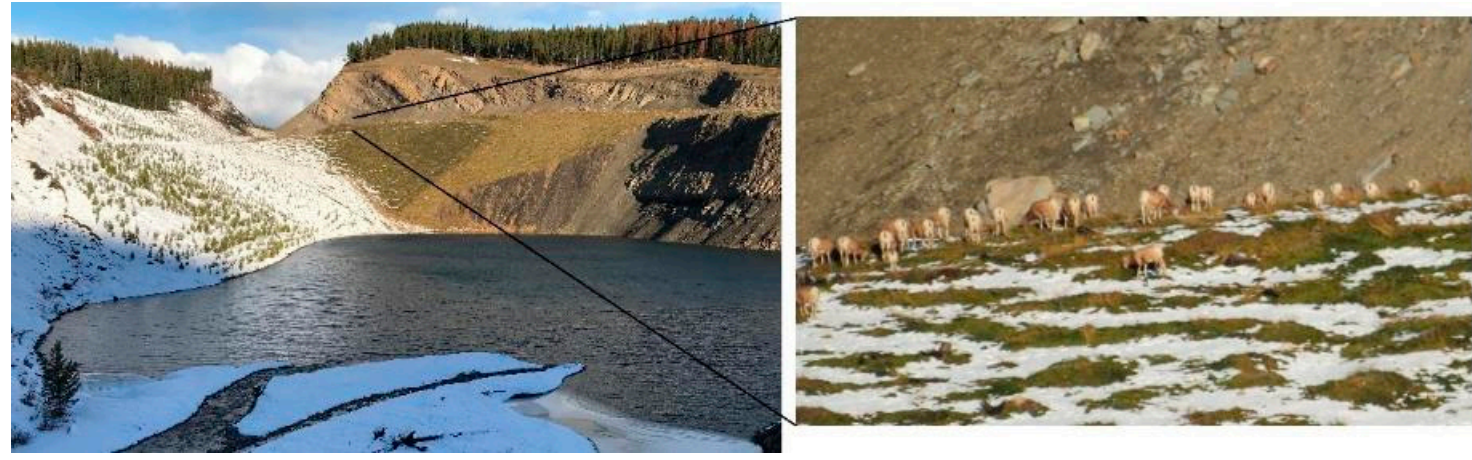

Figure 2. Bighorn Sheep taking advantage of the steep habitat created around Sphinx Pit Lake, Alberta, Canada.

The presence of endangered species of plants and animals has been recorded in a number of sandpit lakes in the Trěboň Basin of the Czech Republic after discontinuation of sand mining [38]. In Denmark, gravel pit lakes were found to be important habitats for communities requiring oligotrophic conditions, which widely get lost in natural lakes due to cultural eutrophication [39].

Sandpit lakes afford an area for new populations of water and marsh plants that are found locally and also regionally within Central Europe. A total of 14 tree species and 59 herbaceous plant species with a minimum cover of $5 \%$ were documented on the 11 monitored sandpit lakes. The sandpit lakes were classified as important biotopes according to the European Union guidelines. Endangered species of vascular plants occur in many sites in the sandpit lakes, such as Illecebrum vercillatum, Lysimachia thyrsiflora, and Lycopodiella inundata.

Similarly, these littoral florae have been found to be an important component of the waterfowl environment. Forty-two species of water birds were recorded in the sandpit lakes belonging to 10 orders [40]. Sandpit lakes were found to represent biotopes that can serve as refuges for the endangered species occurring in the Třeboň Basin Biosphere Reserve: little bittern Ixobrychus minutus and great reed warbler Acrocephalus arundinaceus and potentially for other bird species that may not be as endangered.

\subsection{Fishery}

Fisheries represent a common and often incidental end use for pit lakes where water quality is reasonable to good. However, pit lake fisheries require more considerations than just water quality, with habitat and food sources being important determinants of a successfully sustainable fishery [41,42]. Lower nutrient status often limits primary production and thus fishery food availability $[43,44]$. Conversely, generally good water quality that contains elevated COPC that may biomagnify may actually present a risk to end users, including higher orders of consumers such as birds and mammals, reptiles [45-48], and human game fishers and hunters [49,50].

This may limit the use of pit lakes with low productivity for fisheries. This was reported for well-remediated (including neutralized) German pit lakes in former lignite mines [51] and Swedish gravel pits [39]. However, pit lakes can support a large biodiversity of fish if well managed [52].

Beneficial socio-economic development of the Milada pit lake in Northern Bohemia, Czech Republic, initially led to high densities of cyprinid fish, resulting in eutrophic water conditions [53]. As a result, lake management has featured an extensive stocking and harvesting ecosystem biomanipulation management program since 2005, focusing on lower densities of fish, dominated by piscovores. For example, larger individuals of the traditional game fish pike Esox lucius, zander Sander lucioperca, and wels catfish Silurus glanis perch are still the most abundant predatory fish in the lake. However, dying aquatic macrophyte vegetation as the lake fills means that there may be insufficient habitat for perch egg laying unless artificial habitats are used [54]. 


\subsection{Recreation}

Pit lakes have afforded local populations with both passive and active recreational opportunities in a number of cases studies. Pit lake recreation may be water-based, terrestrial only when water quality is poor or safety issues remain, or a mixture of both [55]. Planning pit lakes for recreation involves a number of factors that must consider human health and safety. Water quality is a key concern [56]; nonetheless, safety aspects of bank steepness [12], shoreline stability [57], and appropriate water depth [58] must also be considered. However, strong competition between sites and communities can develop in new lake districts. In order to avoid failure of investments in new infrastructure for the recreational end use of pit lakes, regional concepts and regional collaboration of all stakeholders are needed [59-61].

In Alberta, Canada, about 25 open cut coal mine pits have been converted into pit lakes that are now used as recreational fisheries and as central features around which hiking trails have been created (Figure 3). Quarry Lake, an abandoned coal mine on the edge of the Rocky Mountains, is a popular destination for angling and hiking [62,63]. For East Pit Lake (resulting from coal mining and filled primarily with groundwater), water-quality monitoring and habitat assessment demonstrated that the lake was suitable for establishing an arctic grayling recreational sport fishery. Alberta Environmental Protection awarded TransAlta a reclamation certificate for the lake in 1994 [64]. Similarly, Lovett and Silkstone pit lakes were created in the 1980s and were used as prototypes for the creation of other sport fisheries from mine pits in the region [33], such as Sphinx Lake, which was created two decades later. In British Columbia, Canada, former mine pits and tailings ponds at a copper mine have been converted into sport fisheries that now host a popular fishing derby [65].

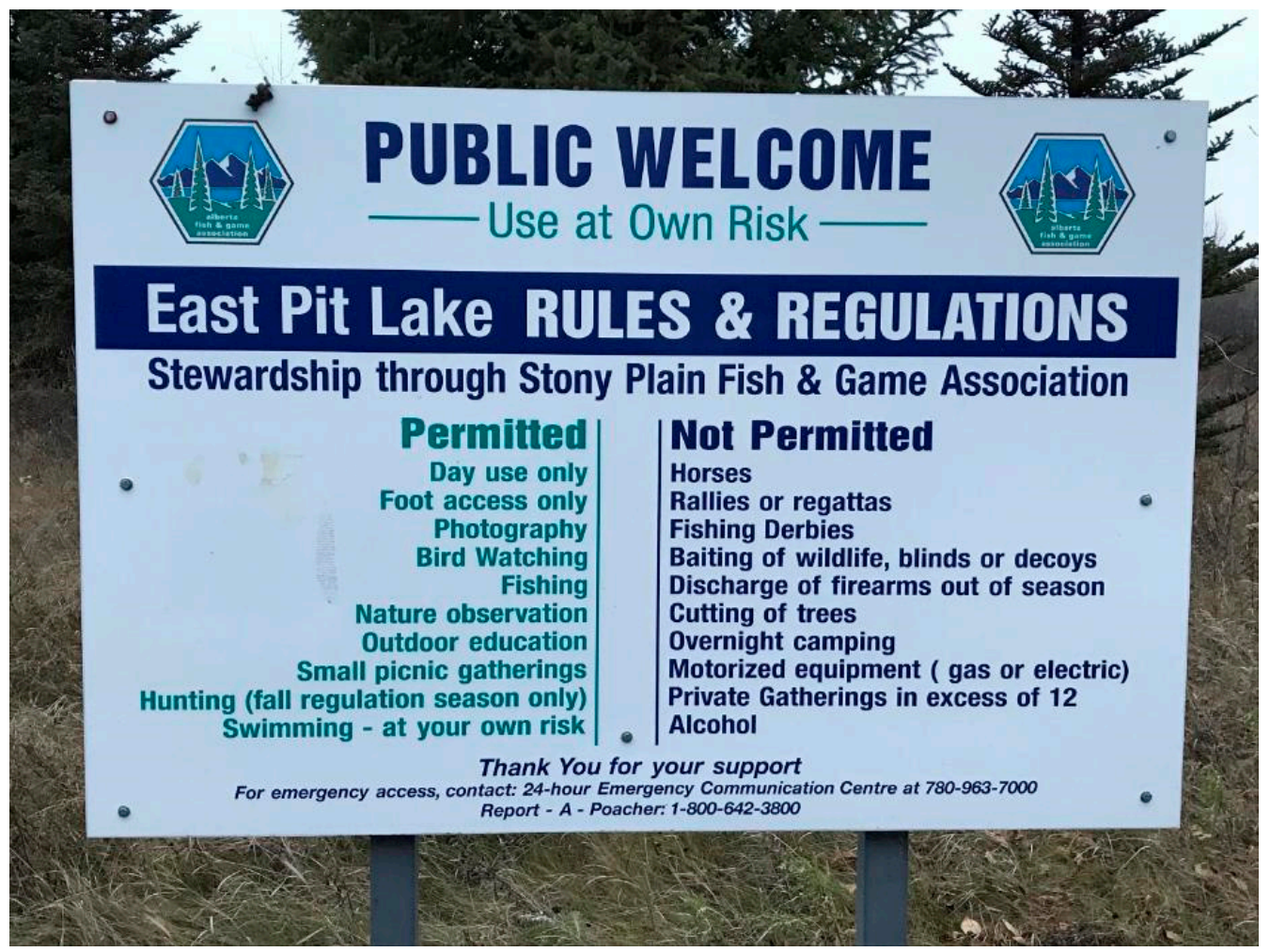

Figure 3. Public end use access sign at East Pit Lake in Alberta, Canada.

Buzzacott and Paine [66] reviewed 157 existing pit lake dive parks worldwide and argued for converting additional mine pits into inland dive parks. The main benefits of such dive parks are that they reduce pressure on sensitive dive sites, especially for diver training, which can entail accidental contact with the substrate, and that they have a longer season due to warmer temperatures than the 
ocean in many locations, which enables divers to maintain their skills and social interactions in the off season.

New lake districts formed in the eastern part of Germany from lignite mining in the Lusatian and in the Central German lignite mining district [67]. For the majority of these lakes, recreation is one of the intended end uses, often the main one. Lake Senftenberg (lake 4 in Figure 7) rapidly became a highly frequented destination for weekend recreation after its filling and neutralization in the 1970s, because the distance to the city of Dresden (ca. 550,000 inhabitants) is only ca. $60 \mathrm{~km}$ and there were not many alternative options for water-related recreation in that region. The increasing attractiveness of Lake Senftenberg and the growing number of new filled pit lakes in its neighborhood are evidenced by the increasing number of visitors staying overnight (Table 2). Connecting Lake Senftenberg and the new pit lakes by canals and water gates (Figure 4; see also Figure 7), allowing for direct travel from lake to lake by boat, certainly contributes to this attractiveness. In the Central German lignite mining district, Linke and Schiffer [68] found that the popularity of the lakes for recreational purposes is strongly related to the distance of the lakes to the two major cities in the region: Leipzig (ca. 580,000 inhabitants) and Halle (ca. 240,000 inhabitants).

Table 2. Tourist data for facilities of the Zweckverband Lausitzer Seenland Brandenburg (Germany) in 1996 and 2018.

\begin{tabular}{ccc}
\hline Type & $\mathbf{1 9 9 6}$ & $\mathbf{2 0 1 8}$ \\
\hline One-day visitors & ca. 700,000 & ca. 800,000 \\
Visitors staying overnight & 19,500 & 62,500 \\
Guest nights & 96,700 & 268,000 \\
Average duration of stay of overnight visitors & 4.96 days & 4.29 \\
\hline
\end{tabular}

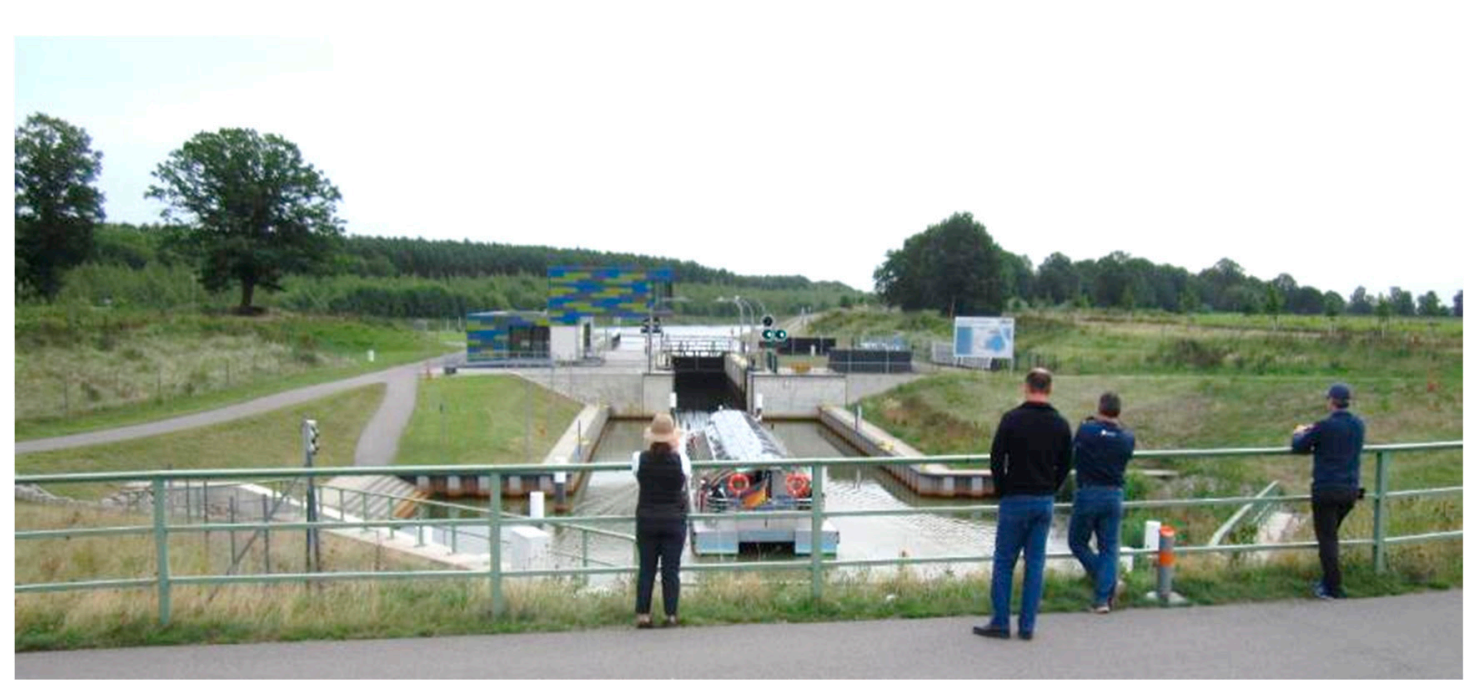

Figure 4. An excursion boat entering the water gate between Lake Senftenberg and Lake Geierswald (lakes 4 and 7 in Figure 7).

In Australia, the Shire of Collie has a population of 9104, and mine pit lakes in the Collie Pit Lake District [69] present recreational opportunities for both residents and tourists to the area. Historically abandoned and unrehabilitated Black Diamond and Stockton Lakes are currently being used as recreational areas [58] (Figure 5). Already rehabilitated and more contemporary, Lake Kepwari is proposed for relinquishment as a recreational facility [70] but is often illegally accessed [71]. 


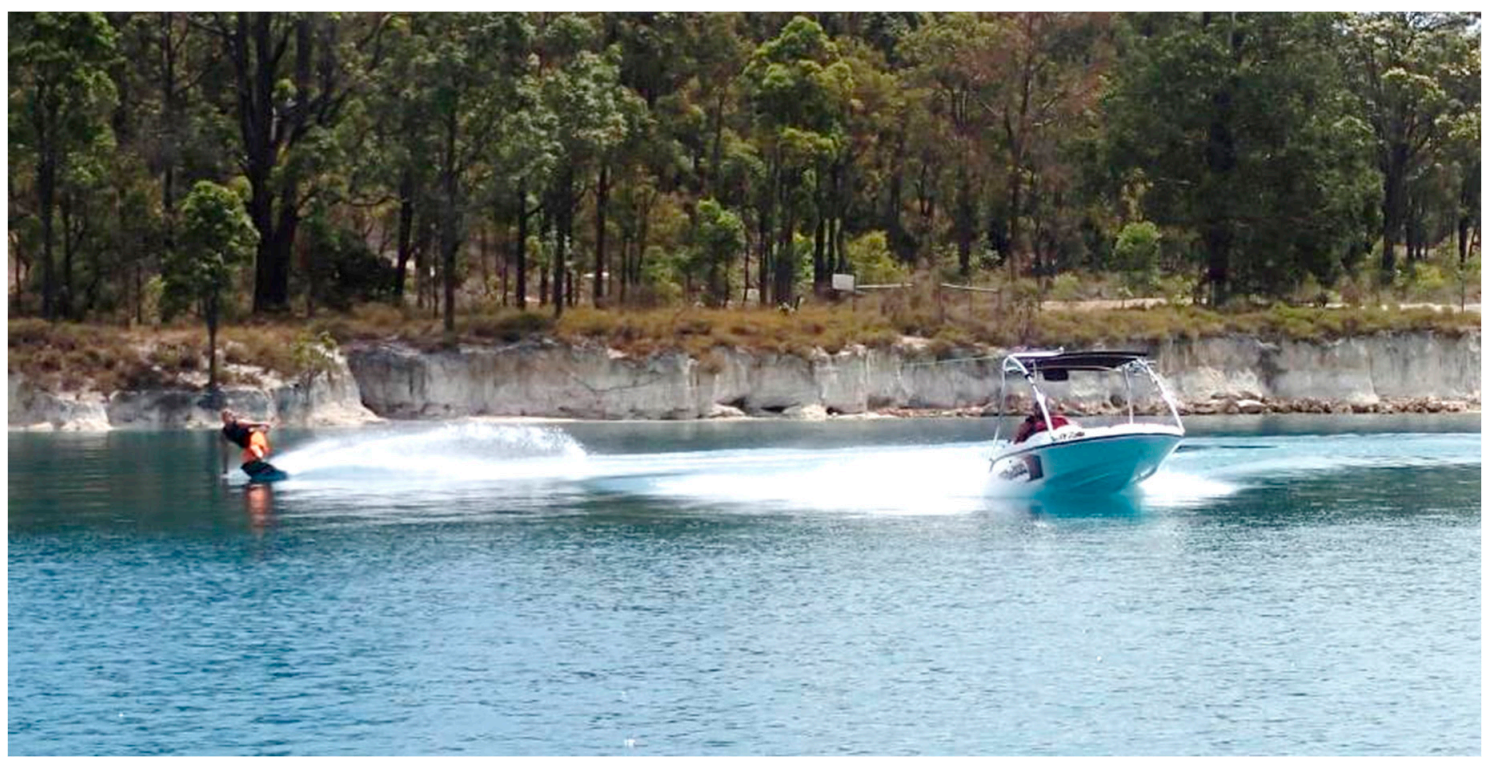

Figure 5. Water skiing on abandoned mine pit lake, Lake Stockton, in Western Australia.

Of the approximately $20 \%$ of residents randomly surveyed, $58.5 \%$ had used the pit lakes in the last two years [56]. Table 3 summarizes the intensity of different types of use of pit lakes near Collie, Western Australia. Of the water-based activities, more time was spent water skiing and boating than other activities. Types of activities undertaken at each lake did not differ by gender, except at Lake Kepwari, where males undertook all of the listed activities, whereas females undertook mainly swimming, wading, boating, and picnicking. A difference in lakes was that the most camping occurred at Lake Stockton, which has a large parking area nearby, and the least boating occurred at Black Diamond, which is a small lake with no defined boat launching areas.

Table 3. Recreational activities undertaken by pit lake users at each of the lakes ( $n=$ number of respondents; the values in the table are the percent of respondents reporting a given use) [56].

\begin{tabular}{ccccc}
\hline Activity & $\begin{array}{c}\text { Black Diamond } \\
(\boldsymbol{n}=\mathbf{1 2 7})\end{array}$ & $\begin{array}{c}\text { Lake Kepwari } \\
(\boldsymbol{n}=\mathbf{3 2})\end{array}$ & $\begin{array}{c}\text { Stockton Lake } \\
(\boldsymbol{n}=\mathbf{1 2 3})\end{array}$ & Other $(\boldsymbol{n}=\mathbf{6})$ \\
\hline Swimming & 83.5 & 53.1 & 72.4 & 50 \\
Kayaking/Canoeing & 15.0 & 3.1 & 15.4 & 33 \\
Wading & 31.5 & 21.9 & 24.4 & 17 \\
Boating & 6.3 & 9.4 & 40.7 & 0 \\
Water skiing & 2.4 & 3.1 & 27.6 & 0 \\
Marroning & 11.0 & 9.4 & 12.2 & 33 \\
Picnicking & 42.5 & 40.6 & 47.2 & 30 \\
Camping & 20.5 & 9.4 & 30.9 & 0 \\
Walking & 7.9 & 9.4 & 2.4 & 17 \\
Fishing & 1.6 & 0.0 & 1.6 & 0 \\
Other & 7.1 & 28.1 & 11.4 & 0 \\
\hline
\end{tabular}

\subsection{Water Source and Storage}

Pit lakes are infrequently used as water sources. Potable uses are typically limited by the presence of alternative, pre-existing water supplies and by often low water quality resulting from elevated geochemical reactivity in void shell rocks and any mine waste backfill materials.

There are several anthropogenic lakes used as freshwater reservoirs in the Czech Republic, especially in large gravel sand mines in southern Moravia near Ostrožská Nová Ves village [72]. Drinking water is also abstracted from bores immediately around the historic gold mine Wedge Lake pit in the Goldfields region of Western Australia [13] (Figure 6). The pit lake and immediate surrounding 
groundwater are low in salinity, hardness, and nitrates and are combined with groundwater from a bore field near the treatment plant.

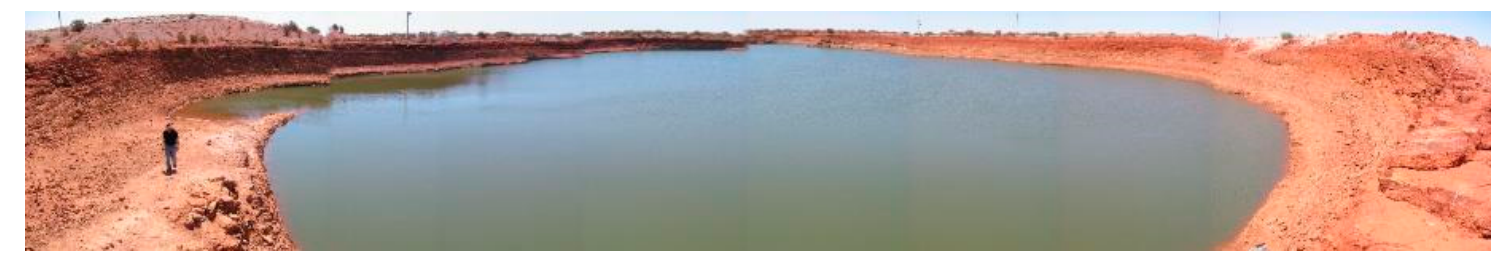

Figure 6. Wedge Pit Lake in arid Western Australia is used as a municipal potable water supply for the nearby town of Laverton.

Several pit lakes in the Lusatian Lignite Mining District (Germany) are used for flood protection and water storage. The stored water is used for regional management of the water balance. The storage capacity of those lakes is provided in Table 4. Figure 7 shows the location of the lakes. The overall storage capacity of German pit lakes used for flood protection and water storage is $264 \times 10^{6} \mathrm{~m}^{3}$ [73] Although this is only a small part of the total volume of German pit lakes, its availability is regionally very important.

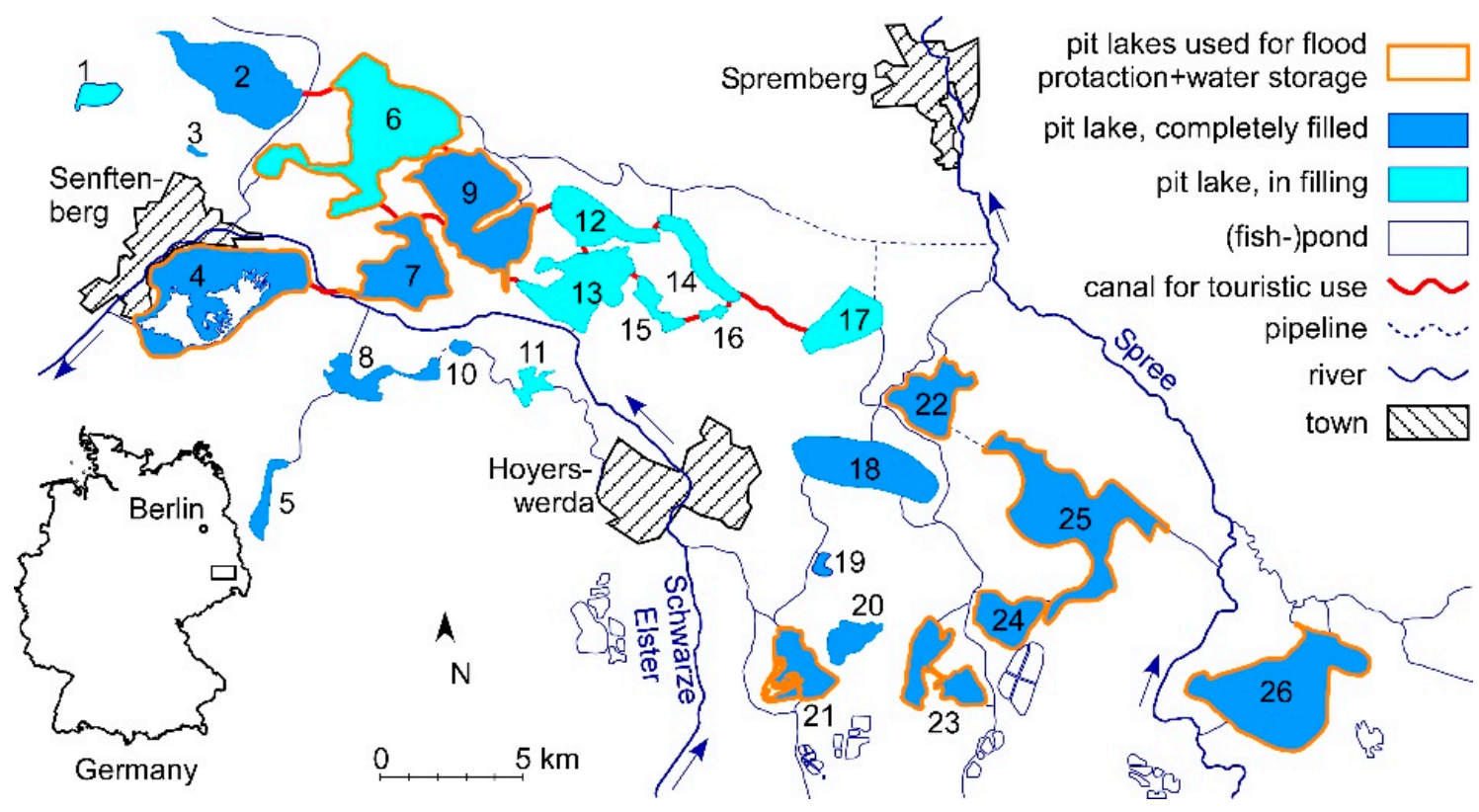

Figure 7. Pit lakes of the central part of the Lusatian Lignite Mining District (Germany). Pit lakes marked by orange lines are used for flood protection and water storage. Canals and water gates connecting pit lakes for touristic use are indicated by red lines. 
Table 4. Storage capacity and total volume of the pit lakes used for flood protection and water storage and shown in Figure 7 (data provided by Landestalsperrenverwaltung des Freistaates Sachsen, Lausitzer und Mitteldeutsche Bergbau-Verwaltungsgesellschaft, Landesamt für Umwelt Brandenburg).

\begin{tabular}{ccccc}
\hline Lake & $\begin{array}{c}\text { Lake } \\
\text { Number }\end{array}$ & $\begin{array}{c}\text { Total Volume (in Case } \\
\text { of Total Filling) } \mathbf{1 0}^{\mathbf{6}} \mathbf{~ m}^{\mathbf{3}}\end{array}$ & $\begin{array}{c}\text { Storage Capacity } \\
\mathbf{1 0}^{\mathbf{6}} \mathbf{~ m}^{\mathbf{3}}\end{array}$ & $\begin{array}{c}\text { Surface Area (in Case of } \\
\text { Total Filling) } \mathbf{~ k m}^{\mathbf{2}}\end{array}$ \\
\hline $\begin{array}{c}\text { Senftenberg } \\
\text { Sedlitz + Geierswald }+\end{array}$ & 4 & 102 & 20.5 & 10.3 \\
Partnitz & $6+7+9$ & $212+98+134$ & 15.0 & $14.2+6.5+11$ \\
Knappenrode & 21 & 18.1 & 6.4 & 2.86 \\
Burghammer & 22 & 35 & 6.0 & 4.82 \\
Lohsa I & 23 & 23.3 & 5.8 & 3.42 \\
Dreiweibern & 24 & 35 & 5.6 & 2.94 \\
Lohsa II & 25 & 97 & 60.5 & 10.8 \\
Bärwalde & 26 & 173 & 25.0 & 13.0 \\
\hline
\end{tabular}

\subsection{Waste Containment and Treatment}

Pit lakes often present an attractive solution for disposal of mine wastes, especially potentially acid-forming (PAF) waste rock and tailings. Subaqueous disposal of mine wastes is considered a best practice in many jurisdictions $[74,75]$, because it limits the mine waste's contact with oxygen and thereby restricts the potential for generation of sulfuric acid from residual sulfides.

The void of the former lignite mine Großkayna (Central German lignite mining district) was partially backfilled with industrial wastes. The wastes mainly consisted of ashes from lignite combustion. Waste materials from the production of nitrogen fertilizer were also deposited among the ashes, leading to ammonia concentrations $>300 \mathrm{mg} / \mathrm{L}$ in pore waters. A pit lake (Lake Runstedt; volume $54 \times 10^{6} \mathrm{~m}^{3}$, area $2.33 \mathrm{~km}^{2}$, maximum depth $33 \mathrm{~m}$ ) was established on top of the waste material by deviating water from the Saale River. By controlling neighboring pit lake water levels, decant of the lake and transport of leachates from the waste into groundwater is prevented [76]. Hypolimnetic aerators are used to enhance nitrification in the hypolimnion, whereas denitrification was proven to occur in the littoral [77].

Creation of water-capped tailings or end pit lakes is also a strategy for permanent storage of fluid fine tailings (FFT) from oil sand processing [78-80]. Both fresh and process-affected waters are used for filling. One function of such lakes is the passive bioremediation of toxic chemicals, such as naphthenic acids and related organic acids [81,82]. Mixing between the mature fine tailings (MFT) that oil sand refining produces and the overlying water cap can be prevented by a sufficient depth of the water layer [83]. Moreover, the lake must not recharge aquifers that are in contact with other sensitive water bodies. However, regulators have not yet approved this concept, and there are remaining uncertainties, such as the rate of detoxification and how microbial metabolism and gas production will affect long-term water quality.

Municipal waste has been disposed of in pit lakes as an end use, this time with an added benefit of potential remediation from the organic materials stimulating alkalinity-generating microbial processes, e.g., sewage [84]. In a scaled series of experiments, green waste and sewage were disposed of from two nearby towns in a highly acidic north Australian coal pit lake [85]. Water quality measures of $\mathrm{pH}$, acidity, and solute concentrations as total dissolved solids (TDS) all improved over the following two years.

Springer Pit Lake is a mine pit at the Mount Polley Mine, a copper mine in BC, Canada (Figure 8). The pit lake stored water and tailings after a tailings storage facility embankment breach on 4 August 2014. Storing tailings in a pit void was considered the best available tailings technology for geotechnical stability [86]. Between August 2014 and August 2015, tailings supernatant water and mine runoff were diverted to the pit lake. Upon resumption of mining in August 2015, mill process water and tailings were also deposited in the pit lake. The pit lake was then used as the primary feed source for water discharge following treatment. After a few months, Springer Pit Lake provided sufficient passive 
water treatment for the active water treatment plant to be switched to "passive mode", meaning that mechanical and chemical additions to the water treatment plant were switched off and only monitoring instruments were left active [80,87]. Water quality in the pit lake followed predictable trajectories [88] and was suitable for discharge to the receiving environment, without active treatment. At present, the pit lake is being drawn down, and tailings are planned to be removed from Springer pit to allow mining to resume in the pit. At mine closure, approximately $15 \mathrm{Mt}$ of PAF waste rock will be placed into the pit, which is a regulatory requirement.

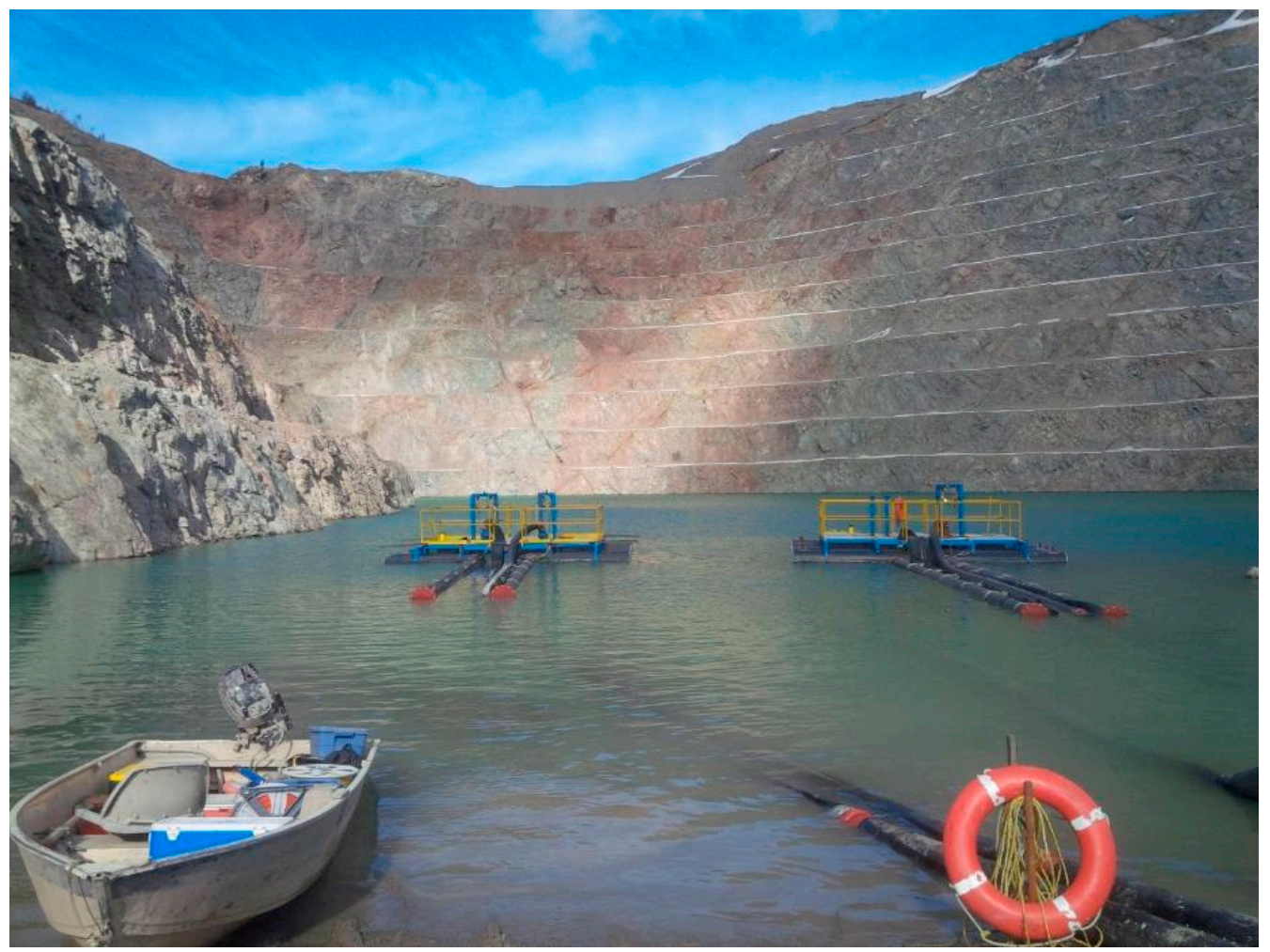

Figure 8. Springer Pit Lake and dewatering infrastructure at Mount Polley Mine, BC, Canada.

\section{Discussion}

Beneficial end use type and outcome varied depending upon climate and commodity, but equally important were social and political dynamics. Initial optimism about likelihood of end uses being successfully realized often failed to meet stakeholder expectations over longer post-closure terms.

Mining company interest and willingness to engage in the repurposing of pit voids as pit lakes with beneficial end uses require a view to innovation outside of typical day-to-day mining activities. Similarly, regulators must have views open to different closure outcomes than they may be used to and regulation may permit [89], with some beneficial outcomes presenting higher risks than more traditional approaches to closure (backfill, fencing, etc.). Third parties, be they investors, community groups, or research organizations, may assist in this process [90].

\subsection{Determinants of End Use Success}

Our review has shown that there are general attributes of pit lake shape, location, type, and closure management that can lead to successful end uses becoming realized.

Some pit lakes have been shown to provide good habitat conditions for the conservation of significant bird life and plant species. Unlike many natural lakes that are now eutrophied by human activities, many pit lakes, especially those from inert geological materials such as sand and aggregate mining, are oligotrophic, which may help prevent out-competing periphytic algal from smothering the 
plants. Although hard-rock mine pit sides are often steep relative to natural lakes, the low stability of their sandy host geology and shallow depth means that littoral areas of some pit lakes, such as in sand quarry operations, may be extensive [91].

Water quality is often the limiting factor to establishing wildlife values in a pit lake; low $\mathrm{pH}$ and elevated metals may make both in-lake fisheries and aquaculture using off-take water unsuccessful or unacceptably high risk for a commercial venture [92]. Conversely, good pit lake water quality may be deteriorated in ultra-oligotrophic and unproductive pit lakes by nutrients from uneaten fish food and from fish waste in in-lake aquaculture operations or by high nutrient concentration discharge [44] (Figure 9).

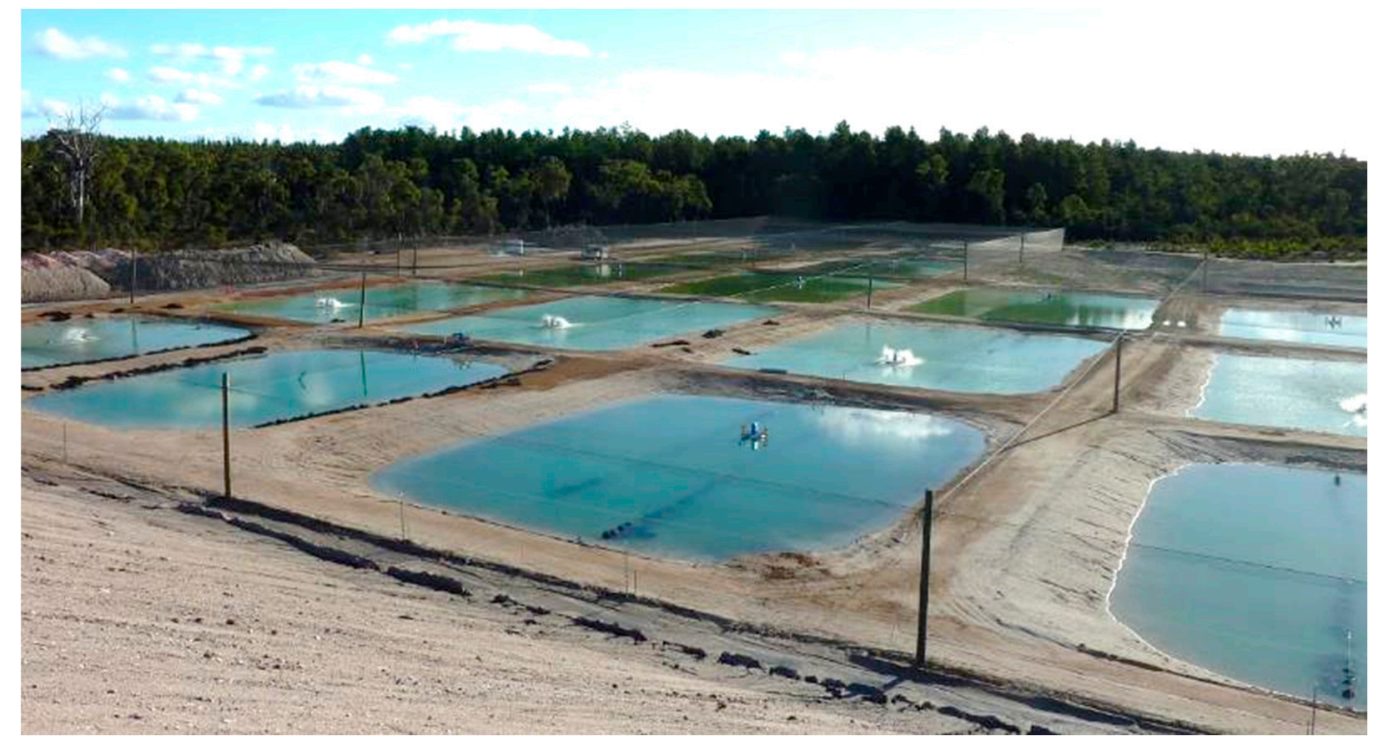

Figure 9. Nutrient-rich discharge to a dystrophic Western Australian coal pit lake from an adjacent aquaculture farm has been found to improve water quality.

Although water quality is key to a successful pit lake fishery, habitat and food availability/quality are also necessary for successful sustainability [41]. For example, substrate for egg spawning [93] or woody and rocky debris for protective shelters [42] were necessary habitat features. The shoreline slope and length are also recognized as important habitat characteristics, with micro-topography of the benthos, such as varied depths, advised to create more a diverse habitat. Shallow wetland areas can also be constructed near inflow areas to mitigate nutrient inputs into the main lake body [94].

Even if fisheries are able to establish, contaminant uptake by fish must be thoroughly assessed [45]. Nonetheless, in locations where the potential for contaminant uptake is high but fish health is maintained, sport fishing or ornamental fish farming can still be employed. Contaminant accumulation can also be reduced through shorter duration fish cultivation (i.e., using fast-growing fish species) and artificial feeding [95].

In the case of direct water contact, recreational uses of lakes will be primarily defined by location and access to human habitation. Exceptionally low turbidity due to low phosphorus availability and thus very little plankton growth can make pit lakes very attractive sites for diving. Dive parks and other water-based recreational uses may be more valuable in regions that do not already have natural lakes in which to recreate or where existing lakes are limited in their recreational opportunities, e.g., by size, shape, and depth or by competing uses such as wildlife values.

Pit lakes can only be successful as water sources if the lakes are of sufficient volume and water quality appropriate to the end use at present and in the long term [72]. Water volume and quality may be inter-related in high net evaporation areas where higher water quality/volume end uses may be 
unsustainable [3]. Water balance and associated water quality modeling can be useful in determining the long-term success of these end uses [96].

Waste deposition requires conditions that limit the transport of contaminants into other components of the environment. Depending on the geological setting and the nature of the mine wastes disposed of, mine closure will need to consider a number of transport pathways, including the atmosphere, surface water, groundwater, and biota. Sealing the mine void shell and capping the waste and hydrological control may be required, depending on ambient conditions.

\subsection{Achieving End Use Success}

A risk-based approach is recommended for determining which end use option might be appropriate in pit lake closure planning, even if no end use is then proposed. A human health and environmental risk assessment (HHERA) approach is more appropriate if the assessment is solely risk-focused, e.g., where end uses are not intended, e.g., Canadian North Environmental Services [97]. However, any end use assessment should also address opportunities and not solely focus on risk, which is likely to increase as opportunity does $[15,98]$. There are various approaches suitable for determining opportunity in concert with risk. A Strength, Weakness, Opportunity, and Threat (SWOT) approach is an appropriate way to assess these options in a risk/opportunity-balanced framework.

By understanding potential risks, early and coordinated research across relevant spatial and temporal scales can be strategically undertaken [85]. Planning and management strategies can also be implemented by mining companies and government agencies so that, post-closure, pit lakes can be used as recreational areas or for other end uses. To ascertain potential for health risks, it is then necessary to determine how often and for what purposes people are using the lakes for recreation so that the level of exposure to physical, chemical, and biological characteristics can be estimated.

Such stakeholder engagement should be early, regular, and transparent in order to achieve the best outcomes of end uses that both match stakeholder expectations and also practicalities [15]. However, such stakeholder aspirations may also change over time, and end use planning should both expect and accommodate these changes [99].

\subsection{General Requirements for Pit Lake End Uses}

Almost all the uses described herein require circum-neutral $\mathrm{pH}$ and low concentrations of contaminants. Only if the pit lake water quality does not present an environmental risk to humans, stock, and wildlife and is not needed for other uses can poor water quality can be acceptable. This acceptance will vary from one jurisdiction to the next depending on stakeholder and regulatory expectations. However, exclusively terrestrial recreational use and non-contact activities, such as boating and other secondary recreation, do not necessarily require neutral $\mathrm{pH}$ and good water quality. In contrast, fisheries require water quality conditions that allow for survival but also for reproduction and adequate growth rates and biomass of recreational fish species [46,48,100]. Contaminant concentrations must also be sufficiently low enough to prevent exceedance of thresholds for ingestion (where required) via bioaccumulation/bioconcentration and by food chain biomagnification [13,45,101-104].

Water quality characteristics must be defined in terms of regional or even site-specific ecology [22,23]. Similarly, water quality for wildlife habitats must be to a standard that not only presents no significant risk to existing environmental receptors that might contact pit lake water, but must also be of a quality that facilitates the development of a sufficiently functional and biodiverse aquatic ecosystem to meet stakeholder expectations [43,49]. Caution should be taken, however, that biodiversity within a pit lake is unlikely to reach the levels found in natural lakes within a given region, due to a number of limiting factors. Generally, water quality must be appropriate for the specifically desired ecosystem in terms of toxicity (metals in particular, and accounting for both chronic toxicity and bioconcentration to higher food chain levels). Although often not considered with the focus on toxicants, nutrient must also be of appropriate concentrations, especially in terms of available 
phosphorus, which is typically limiting in freshwater ecosystems [24,25] and more so in pit lakes with elevated iron and aluminum concentrations that co-precipitate phosphorus [26-28].

A human health and ecological risk assessment is an appropriate tool for determining risks to in-pit and out-pit wildlife values $[43,49,50,97]$. Pit lake water treatment may also be the only viable option for legacy pit lakes that were filled before closure plans were contemplated (Hamblin, 1999 \#1778). Similarly, protection of any downstream aquatic ecosystems that might reasonably be expected to receive pit lake decant should be considered. Pit lakes in areas of nature conservation may not require treatment if there are alternative water resources for wildlife around. This has been done at least with some lakes in Lusatia and one close to Bitterfeld. In such cases, treating not the lake itself but rather outflowing waters has been found to be a better option to avoid disturbance inside the protected area.

Furthermore, the presence of (or possibly construction thereof) aquatic benthic/littoral $[29,30]$ and riparian habitat [31] will also be an important consideration if a wildlife habitat is a desired end use [32-36]. Such a habitat will be especially important for more complex biota, such as amphibians, reptiles, birds, and mammals, but may also be important for zooplankton [37]. The habitat will require appropriate attributes from both abiotic (e.g., shallow or steep slopes, sediment either fine or coarse) and biotic (e.g., vegetation both living and dead) contributions.

All pit lakes where swimming is expected to occur (either planned or unplanned) as an end use should include safe areas for access and egress. This safe access also facilitates monitoring and allows wildlife and livestock to access lake water safely. However, water depth may also be important for recreational activities, including swimming, boating/water skiing, and underwater diving [58].

As a direct consequence, slope stability (geotechnical and erosion) must be a fundamental consideration for almost all pit lake end uses [57]. Only in areas without risk to human safety might pit wall and shoreline instability be acceptable. For example, nature conservation or low value stock grazing areas may fulfill this condition. This includes the risk attributed to surge waves within and downstream of pit lakes resulting from mass slope failures. Besides regrading to less erosive and more geotechnically stable shorelines, there are many options to restrict (only inadvertent) human and deliberate animal access to unstable pit lake shorelines, including warning signage, dense plantings of more difficult to traffic vegetation, and, at the most extreme case, fences that will be maintained in perpetuity. However, the expected local practice regarding the responsibility of land owners differs between jurisdictions and must to be considered [105-107].

\section{Conclusions}

As with many mine closure outcomes, examples of end use development as a closure strategy are rarely published, and this is more often the case when they are not successful [108]. In particular, academic research (often by graduate and postgraduate students) on abandoned mine pit lake end uses often does not progress past industry reports and academic theses and dissertations [90]. We collated information on geographic and physical attributes and pit lake end use outcomes to determine what lessons might be gleaned to improve pit lake closure practice and outcomes.

Common attributes and reasons that led to successful closure outcomes as end use developments included not only multidisciplinary contributions, but also a transdisciplinary approach to planning. Current closure planning often involves, and is recommended to involve, a host of different technical experts $[109,110]$. In this less common approach to closure and abandoned asset planning [111], technical experts engage with each other to achieve a common and not just specialist outcome (Figure 10) [63,109,111]. This contribution involves technical experts from allied disciplines and tended to work best when these experts had experience with other pit lake successes. Another key attribute of transdisciplinary planning is the workshop approach, where relevant experts interact collectively, rather than in stepwise or piecemeal fashion. Additionally, social engagement ensures that stakeholders are abreast of technical issues and that stakeholder views themselves can be incorporated into the outcomes of technical assessments [112-114]. 


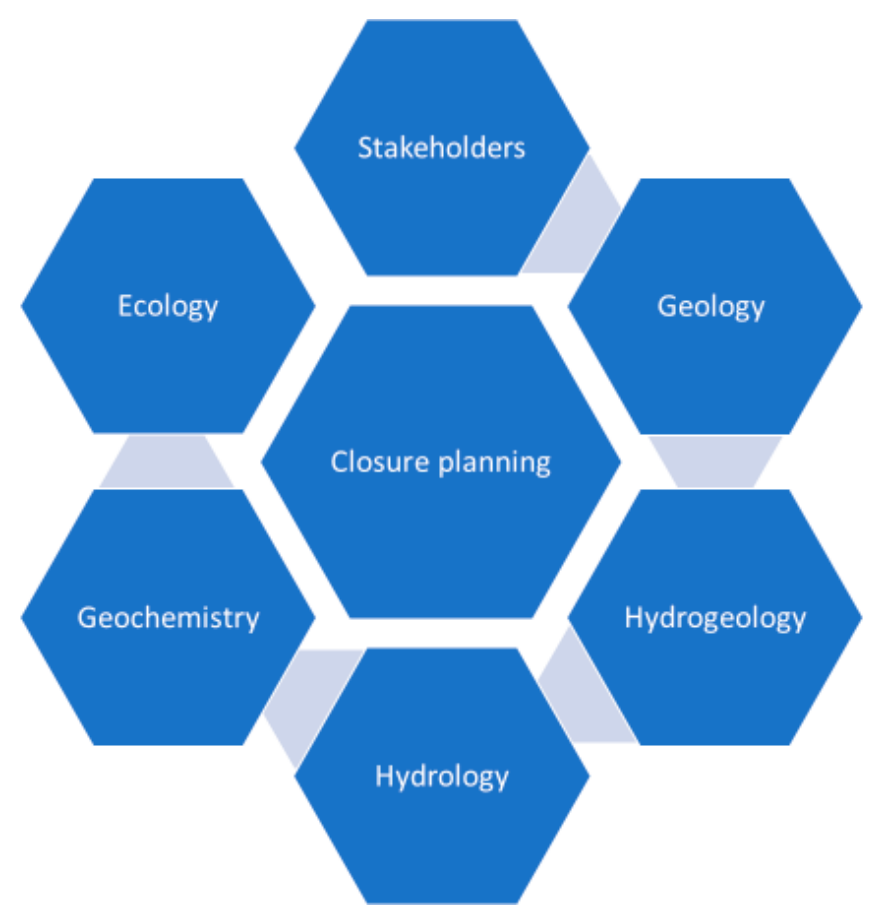

Figure 10. A transdisciplinary approach to opportunity planning of pit lakes.

Furthermore, a number of practices were noted to lead to successful outcomes. These practices include early planning and incorporation of closure considerations into mining plans; early and regular engagement with regulators and other stakeholders (and vice versa); consideration of long-term effects of climate and regional socio-economic dynamics; good water quality of source waters (through good waste management and also fewer geochemical issues in mine waste and pit void shell exposures); and relatively significant contributions of good water quality to the pit lake, e.g., through rapid filling [115-117] or ongoing flushing, such as flow-through [70,118].

Different end uses require different water quality and habitat structures. While low biological productivity is favored for recreational diving, a sustainable fishery requires higher productivity. Dense standings of macrophytes, favored by large littoral zones and shallow depth, may hinder swimming. Therefore, not all potential uses can be combined in every single lake, in particular in the case of small lakes. However, if there are several lakes close to each other, they may allow for multiple uses in a spatially separated layout, e.g., recreation and nature conservation. Good design and management (considered guidance, smart location, and infrastructure development, particularly access roads and exceptionally attractive recreational facilities) allow for directing activities and managing intensity of use [119].

Because water depth is a decisive factor for the occurrence of seasonal thermal stratification and the amount of oxygen available in the hypolimnion during stratification, the shaping of the final mine void and the defined final water level have considerable influence on the recycling of phosphorus (so-called internal loading; see Nürnberg [120]) and other chemicals from the sediment. In other words, future water quality problems can be mitigated by appropriate design of the final mine void.

Finally, regionally and locally applicable legal requirements regarding not just broader mine closure, but more specifically, water quality, slope stability, and safety must be fulfilled for pit lake end uses to be successfully realized. Where end uses are expected to provide for sustainable economic opportunity, socio-economic considerations must also prevail [105-107].

Author Contributions: Conceptualization, C.D.M.; methodology, C.D.M.; data curation, C.D.M.; writing-original draft preparation, C.D.M., M.S., and J.V.; writing-review and editing, C.D.M., M.S., and J.V. All authors have read and agreed to the published version of the manuscript. 
Funding: This research received no external funding.

Acknowledgments: We are grateful to Zweckverband Lausitzer Seenland Brandenburg (Senftenberg, Germany) for providing numbers of visitors in its touristic facilities and to Landestalsperrenverwaltung des Freistaates Sachsen (Pirna, Germany), Lausitzer und Mitteldeutsche Bergbau-Verwaltungsgesellschaft (Senftenberg, Germany), and Landesamt für Umwelt Brandenburg (Potsdam, Germany) for providing data on pit lakes used for flood protection and water storage.

Conflicts of Interest: The authors declare no conflict of interest.

\section{References}

1. Castro, J.M.; Moore, J.N. Pit lakes: Their characteristics and the potential for their remediation. Environ. Earth Sci. 2000, 39, 1254-1260. [CrossRef]

2. Werner, F.; Bilek, F.; Luckner, L. Impact of regional groundwater flow on the water quality of an old post-mining lake. Ecol. Eng. 2001, 17, 133-142. [CrossRef]

3. McCullough, C.D.; Marchand, G.; Unseld, J. Mine Closure of Pit Lakes as Terminal Sinks: Best Available Practice When Options are Limited? Mine Water Environ. 2013, 32, 302-313. [CrossRef]

4. McCullough, C.D.; Harkin, C. Engineered Flow-through Closure of an Acid Pit Lake: A Case Study. In Proceedings of the International Mine Closure 2015 Congress, Vancouver, BC, Canada, 1-3 June 2015.

5. McCullough, C.D.; Schultze, M. Riverine Flow-through of Mine Pit Lakes: Improving Both Mine Pit Lake and River Water Quality Values? In Proceedings of the Joint International Conference on Acid Rock Drainage ICARD/International Mine Water Association (IMWA) Congress, Santiago, Chile, 28 April-1 May 2015.

6. Doupé, R.G.; Lymbery, A.J. Environmental Risks Associated with Beneficial End Uses of Mine Lakes in Southwestern Australia. Mine Water Environ. 2005, 24, 134-138. [CrossRef]

7. Vandenberg, J.A.; McCullough, C.D.; Bolan, N.; Kirkham, M.; Ok, Y. Key Issues in Mine Closure Planning for Pit Lakes. In Spoil to Soil; Informa UK Limited: Colchester, UK, 2017; pp. 175-188.

8. Eary, T.; Castendyk, D. Hardrock Metal Mine Pit Lakes: Occurrence and Geochemical Characteristics. In Acidic Pit Lakes_Legacies of Surface Mining on Coal and Metal Ores; Geller, W., Schultze, M., Kleinmann, R.L.P., Wolkersdorfer, C., Eds.; Springer: Berlin, Germany, 2012; pp. 75-106.

9. Friese, K.; Herzsprung, P.; Schultze, M. Water, Sediment, and Pore Water. In Acidic Pit Lakes-Legacies of Surface Mining on Coal and Metal Ores; Geller, W., Schultze, M., Kleinmann, R.L.P., Wolkersdorfer, C., Eds.; Springer: Berlin, Germany, 2012; pp. 42-57.

10. Nestler, P.; Stoll, R.D. Stabilisation of Bank Slopes That Are Prone to Liquefaction in Ecologically Sensitive Areas. Waste Manag. 2001, 21, 153-159. [CrossRef]

11. Van Zyl, D. Slope Stability Considerations. In Mine Pit Lakes: Characteristics, Predictive Modeling, and Sustainability; Castendyk, D.N., Eary, L.E., Eds.; Society for Mining, Metallurgy, and Exploration (SME): Englewood, CO, USA, 2009; pp. 269-273.

12. Ross, T.; McCullough, C.D. Health and Safety Working around Pit Lakes. In Mine Pit Lakes: Closure and Management; McCullough, C.D., Ed.; Australian Centre for Geomechanics: Perth, Australia, 2011; pp. 167-181.

13. McCullough, C.D.; Lund, M.A. Opportunities for Sustainable Mining Pit Lakes in Australia. Mine Water Environ. 2006, 25, 220-226. [CrossRef]

14. Geller, W.; Schultze, M.; Wisotzky, F. Remediation and Management of Acidified Pit Lakes and Outflowing Waters. In Acidic Pit Lakes_Legacies of Surface Mining on Coal and Metal Ores; Geller, W., Schultze, M., Kleinmann, R.L.P., Wolkersdorfer, C., Eds.; Springer: Berlin, Germany, 2013; pp. 225-264.

15. McCullough, C.D.; Hunt, D.; Evans, L.H. Sustainable Development of Open Pit Mines: Creating Beneficial End Uses for Pit Lakes. In Mine Pit Lakes: Characteristics, Predictive Modeling, and Sustainability; Castendyk, D.N., Eary, L.E., Eds.; Society for Mining, Metallurgy, and Exploration (SME): Englewood, CO, USA, 2009; pp. 249-268.

16. McCullough, C.D.; Schultze, M. Risks and Rewards of Pit Lakes. AusIMM Bull. 2018, 2018, 38-41.

17. DIIS. Leading Practice Sustainable Development Program for the Mining Industry_Preventing Acid and Metalliferous Drainage Handbook; Department of Industry, Innovation and Science (DIIS): Canberra, Australia, 2016.

18. Castendyk, D.; Eary, T. The Nature and Global Distribution of Pit Lakes. In Mine Pit Lakes: Characteristics, Predictive Modeling, and Sustainability; Castendyk, D.N., Eary, L.E., Eds.; Society for Mining, Metallurgy, and Exploration (SME): Englewood, CO, USA, 2009; pp. 1-11. 
19. Bylak, A.; Rak, W.; Wójcik, M.; Kukuła, E.; Kukuła, K. Analysis of Macrobenthic Communities in a Post-Mining Sulphur Pit Lake (Poland). Mine Water Environ. 2019, 38, 536-550. [CrossRef]

20. Kamberović, J.; Arudanović, S. Algae and Macrophytes of Mine Pit Lakes in the Wider Area of Tuzla, Bosnia and Herzegovina. Nat. Croat 2012, 21, 101-118.

21. Otahel'ová, H.; Ot'ahel', J. Distribution of Aquatic Macrophytes in Pit Lakes in Relation to the Environment (Borská Nížina Lowland, Slovakia). Eklógia 2006, 25, 398-411.

22. Van Dam, R.A.; Humphrey, C.L.; Harford, A.J.; Sinclair, A.C.; Jones, D.R.; Davies, S.; Storey, A.W. Site-Specific Water Quality Guidelines: 1. Derivation Approaches Based on Physicochemical, Ecotoxicological and Ecological Data. Environ. Sci. Pollut. Res. 2014, 21, 118-130. [CrossRef] [PubMed]

23. Hall, L.W., Jr.; Giddings, J.M. The Need for Multiple Lines of Evidence for Predicting Site-Specific Ecological Effects. Hum. Ecol. Risk Assess. 2000, 6, 679-710. [CrossRef]

24. Donali, E.; Brettum Løvik, J.E.; Lyche-Solheim, A.; Andersen, T. Pelagic Response of a Humic Lake to Three Years of Phosphorus Addition. Can. J. Fish. Aquat. Sci. 2005, 62, 322-332. [CrossRef]

25. Maavara, T.; Parsons, C.T.; Ridenour, C.; Stojanovic, S.; Durr, H.H.; Powley, H.R.; Van Cappellen, P. Global Phosphorus Retention by River Damming. Proc. Natl. Acad. Sci. USA 2015, 112, 15603-15608. [CrossRef]

26. Grüneberg, B.; Kleeberg, A. Phosphorus in Acidic Mining Lakes: Importance and Biogeochemical Cycling. In Acidic Pit Lakes_Legacies of Surface Mining on Coal and Metal Ores; Geller, W., Schultze, M., Kleinmann, R.L.P., Wolkersdorfer, C., Eds.; Springer: Berlin, Germany, 2013; pp. 62-75.

27. Hupfer, M.; Fischer, P.; Friese, K. Phosphorus Retention Mechanisms in the Sediment of an Eutrophic Mining Lake. Water Air Soil Pollut. 1998, 141, 341-352. [CrossRef]

28. Kleeberg, A.; Grüneberg, B. Phosphorus Mobility in Sediments of Acid Mining Lakes, Lusatia, Germany. Ecol. Eng. 2005, 24, 89-100. [CrossRef]

29. Pal, S.; Kumar Mukherjee, A.; Senapati, T.; Samanta, P.; Mondal, S.; Ratan Ghosh, A. Study on Littoral Zone Sediment Quality and Aquatic Macrophyte Diversity of Opencast Coal Pit-Lakes in Raniganj Coal Field, West Bengal, India. Int. J. Environ. Sci. 2014, 4, 575-588.

30. Kosík, M.; Čadková, Z.; Přikryl, I.; Sed’a, J.; Pechar, L.; Pecharová, E. Initial Succession of Zooplankton and Zoobenthos Assemblages in Newly Formed Quarry Lake Medard (Sokolov, Czech Republic). In Proceedings of the International Mine Water Association (IMWA) Congress, Aachen, Germany, 4-11 September 2011.

31. Van Etten, E.J.B. The Role and Value of Riparian Vegetation for Mine Pit Lakes. In Mine Pit Lakes: Closure and Management; McCullough, C.D., Ed.; Australian Centre for Geomechanics: Perth, Australia, 2011; pp. 91-105.

32. Brinker, C.J.; Symbaluk, M.D.; Boorman, J.G. Constructing Habitat for Sustainable Native Fisheries in the Sphinx Lake End Pit Lake System. In Proceedings of the Sixth International Conference on the Mine Closure, Perth, Australia, 18-21 September 2011.

33. Hildebrand, L.; Noton, R.L.; Anderson, J.W. Lake Development and Fish Habitat Enhancement at Coal Valley, Alberta. 83. 1982; Prepared for Luscar Ltd.; R.L. \& L. Environmental Services Ltd.: Edmonton, AB, Canada, 1982.

34. Larratt, H.M.; Freberg, M.; Hamaguchi, B.A. Developing Tailings Ponds and Pit Lakes as Bioreactors and Habitat Cost-Effective Successes at Highland Valley Copper. In Proceedings of the British Columbia Mine Reclamation Symposium, Squamish, BC, Canada, 17-20 September 2007.

35. Sinclair, G.; Fawcett, M. Development of an Aquatic Habitat and Water Resource in Closing out the Enterprise Pit; Australasian Inst Min Metall: Melbourne, Australia, 1994; pp. 447-457.

36. Smokorowski, K.E.; Kelso, J.R.M.; Geiling, W.D. Experimental Manipulation of Aquatic Habitat in Decommissioned Aggregate Pits and Quarries To: (A) Determine the Role of Habitat in Shaping Fish Communities and (B) Identify Effective Options for Reclaiming Sites with Fisheries Potential. In Proceedings of the Sudbury 2003-Mining and the Environment, Laurentian University, Sudbury, ON, Canada, 25-28 May 2003.

37. Balvert, S.F.; Duggan, I.C.; Hogg, I.D. Zooplankton Season Dynamics in a Recently Filled Mine Pit Lake: The Effect of Non-Indigenous Daphnia Establishment. Aquat. Ecol. 2009, 43, 403-413. [CrossRef]

38. Krivácková, O.; Pecharová, E.; Cížková, H. Sandpit Lakes Vegetation in the Třeboň Biosphere Reserve: Effect of Anthropogenic Activities. Ekologia 2006, 25, 270-281.

39. Søndergaard, M.; Lauridsen, T.L.; Johansson, L.S.; Jeppesen, E. Gravel Pit Lakes in Denmark: Chemical and Biological State. Sci. Total Environ. 2018, 612, 9-17. [CrossRef] 
40. Rajchard, J.; Fridrichovský, V.; Krivácková, O.; Navrátilová, J. Colonisation by Waterbirds of Artificial Lakes after Surface Mining: A Case Study. Acta Zool. Sin. 2006, 54, 602-614.

41. Lund, M.A.; McCullough, C.D. Restoring Pit Lakes: Factoring in the Biology. In Mine Pit Lakes: Closure and Management; McCullough, C.D., Ed.; Australian Centre for Geomechanics: Perth, Australia, 2011; pp. 83-90.

42. McCullough, C.D.; Steenbergen, J.; te Beest, C.; Lund, M.A. More Than Water Quality: Environmental Limitations to a Fishery in Acid Pit Lakes of Collie, South-West Australia. In Proceedings of the International Mine Water Conference, Pretoria, South Africa, 19-23 October 2009.

43. Hakonson, T.E.; Meyer, V.F.; Dean, A. Significance of Biological Productivity of Pit Lakes for Interpreting Ecological Risks. In Mine Pit Lakes: Characteristics, Predictive Modeling, and Sustainability; Castendyk, D.N., Eary, L.E., Eds.; Society for Mining, Metallurgy, and Exploration (SME): Englewood, CO, USA, 2009; pp. 179-187.

44. Kumar, R.N.; McCullough, C.D.; Lund, M.A.; Larranãga, S. Assessment of Factors Limiting Algal Growth in Acidic Pit Lakes-A Case Study from Western Australia, Australia. Environ. Sci. Pollut. Res. 2016, 23, 5915-5924. [CrossRef] [PubMed]

45. Miller, L.L.; Rasmussen, J.B.; Palace, V.P.; Sterling, G.; Hontela, A. Selenium Bioaccumulation in Stocked Fish as an Indicator of Fishery Potential in Pit Lakes on Reclaimed Coal Mines in Alberta, Canada. Environ. Manag. 2013, 52, 72-84. [CrossRef] [PubMed]

46. Miller, L.L.; Rasmussen, J.B.; Palace, V.P.; Hontela, A. The Physiological Stress Response and Oxidative Stress Biomarkers in Rainbow Trout and Brook Trout from Selenium-Impacted Streams in a Coal Mining Region. J. Appl. Toxicol. 2009, 29, 681-688. [CrossRef]

47. Wayland, M.; Kneteman, J.; Crosley, R. The American Dipper as a Bioindicator of Selenium Contamination in a Coal Mine-Affected Stream in West-Central Alberta, Canada. Environ. Monit. Assess. 2006, 123, 285-298. [CrossRef]

48. Palace, V.P.; Baron, C.; Evans, R.E.; Holm, J.; Kollar, S.; Wautier, K.; Werner, J.; Siwik, P.; Sterling, G.; Johnson, C.F. An Assessment of the Potential for Selenium to Impair Reproduction in Bull Trout, Salvelinus confluentus, from an Area of Active Coal Mining. Environ. Biol. Fishes 2004, 70, 169-174. [CrossRef]

49. Nicholson, A.; Rudnick, D.; Willliams, L.; Ortega, J. Spatial and Temporal Assessment of Ecological Risks at a Gold Mine Pit Lake. In Proceedings of the International Mine Water Association (IMWA) Conference, Golden, CO, USA, 30 September-4 October 2013.

50. Sampson, J.R.; Mellott, R.S.; Pastorok, R.A. Ecological Risk Assessment for a Mine Pit Lake, Nevada, USA. In Proceedings of the British Columbia Mine Reclamation Symposium, Kamloops, BC, Canada, 17-20 June 1996.

51. Rümmler, F.; Ritterbusch, D.; Schiewe, S.; Weichler, F.; Füllner, G. Erschließung Neuer Ressourcen Für Die Sächsische Fischerei Durch Maränenbewirtschaftung Von Tagebaurestseen. Schr. Sächsischen Landesanst. Landwirtsch. 2005, 10, 54-151.

52. Matern, S.; Emmrich, M.; Klefoth, T.; Wolter, C.; Nikolaus, R.; Wegener, N.; Arlinghaus, R. Effect of recreational-fisheries management on fish biodiversity in gravel pit lakes, with contrasts to unmanaged lakes. J. Fish Biol. 2019, 94, 865-881. [CrossRef]

53. Peterka, J.; Čech, M.; Draštík, V.; Jůza, T.; Frouzová, J.; Prchalová, M.; Kubečka, J. Ten Years of Fish Community Succession in Post-Mining Lake Milada-Chabařovice. In Proceedings of the International Mine Water Association (IMWA) Congress, Aachen, Germany, 4-11 September 2011.

54. Čech, M.; Peterka, J.; Říha, M.; Draštík, V.; Kratochvíl, M.; Kubečka, J. Deep spawning of perch (Perca fluviatilis, L.) in the newly created Chabařovice Lake, Czech Republic. Hydrobiologia 2010, 649, 375-378. [CrossRef]

55. Gerner, M.; McCullough, C.D. Planning for a Positive Future: Development of Beneficial End Uses from a Quarry Pit Lake, Victoria, Australia. In From Start to Finish: A Life of Mine Perspective; AusIMM: Brisbane, Australia, 2018; pp. 249-258.

56. Hinwood, A.L.; Heyworth, J.; Tanner, H.; McCullough, C. Recreational Use of Acidic Pit Lakes-Human Health Considerations for Post Closure Planning. J. Water Resour. Prot. 2012, 4, 1061-1070. [CrossRef]

57. McCullough, C.D.; van Rooijen, A.; van Maren, B. Process-Based Shoreline Erosion Modelling for Batter Design of a Coal Mine Pit Lake. In Proceedings of the Fourteenth International Conference on Mine Closure, Perth, Australia, 3-5 September 2019. 
58. Carlino, A.; McCullough, C.D. Modelling the Long-Term Water Balance of a Pit Lake for Recreational End Uses. In Proceedings of the Fourteenth International Conference on Mine Closure, Perth, Australia, 3-5 September 2019.

59. Berkner, A. Seenverbünde in Der Neuen Wasserlandschaft Mitteldeutschland. In Braunkohlenplanung, Bergbaufolgelandschaften, Wasserhaushaltssanierung-Arbeitsmaterial der Akademie für Raumforschung und Landesplanung Hannover Nr. 323; Berkner, A., Thieme, T., Eds.; Akademie für Raumforschung und Landesplanung: Hannover, Germany, 2005.

60. Seifert, P. Urlaubsgäste Statt Kohlekumpel? Die Nutzung Des Rheinischen, Mitteldeutschen Und Lausitzer Reviers Für Die Erholung. In Braunkohlenplanung, Bergbaufolgelandschaften, Wasserhaushaltssanierung-Arbeitsmaterial der Akademie für Raumforschung und Landesplanung Hannover Nr. 323; Berkner, A., Thieme, T., Eds.; Akademie für Raumforschung und Landesplanung: Hannover, Germany, 2005.

61. Heidenfelder, R.; Schneider, K. Wassertouristische Potenziale in Der Lausitz Zwischen Iba Fürst-Pückler-Land, Seenverbund Und Erlebniswelt. In Braunkohlenplanung, Bergbaufolgelandschaften, Wasserhaushaltssanierung_-Arbeitsmaterial der Akademie für Raumforschung und Landesplanung Hannover Nr. 323; Berkner, A., Thieme, T., Eds.; Akademie für Raumforschung und Landesplanung: Hannover, Germany, 2005.

62. Tourism Canmore. Quarry Lake. Available online: http://www.tourismcanmore.com/things-to-do/quarrylake (accessed on 8 April 2017).

63. Stephenson, H.G.; Castendyk, D. The Reclamation of Canmore Creek-An Example of a Successful Walk Away Pit Lake Closure. Min. Eng. 2019, 71, 20.

64. Sumer, S.; Pitts, L.; McCulloch, J.; Quan, H. Alberta Lake Re-Established after Draining to Mine Coal. Min. Eng. 1995, 47, 1015-1019.

65. Teck. Reclamation-Example-From-a-Tailings-Pond-to-a-Trout-Pond. Available online: https://www. teck.com/news/stories/2016/reclamation-example---from-a-tailings-pond-to-a-trout-pond (accessed on 9 December 2019).

66. Buzzacott, P.; Paine, D. Former Pit Mine Dive Parks. In Proceedings of the International Mine Water Association (IMWA) Congress, Bunbury, Australia, 30 September-4 October 2012.

67. Schultze, M.; Hemm, M.; Geller, W.; Benthaus, F.-C. Pit Lakes in Germany: Hydrography, Water Chemistry and Management. In Acidic Pit Lakes_Legacies of Surface Mining on Coal and Metal Ores; Geller, W., Schultze, M., Kleinmann, R.L.P., Wolkersdorfer, C., Eds.; Springer: Berlin, Germany, 2013; pp. 265-291.

68. Linke, S.; Schiffer, L. Development Prospects for the Post-Mining Landscape in Central Germany. In Remediation of Abandoned Surface Coal Mining Sites: A NATO-Project; Mudroch, A., Stottmeister, U., Kennedy, C., Klapper, H., Eds.; Springer: Heidelberg, Germany, 2001.

69. Lund, M.A.; McCullough, C.D.; Kumar, N.R. The Collie Pit Lake District, Western Australia: An Overview. In Proceedings of the International Mine Water Association (IMWA) Congress, Bunbury, Australia, 29 September-4 October 2012.

70. McCullough, C.D. Consequences and Opportunities of River Breach and Decant from an Acidic Mine Pit Lake. Ecol. Eng. 2015, 85, 328-338. [CrossRef]

71. Hinwood, A.L.; Heyworth, J.; Tanner, H.; McCullough, C.D. Mine Voids Management Strategy (II): Review of Potential Health Risks Associated with Recreational Use of the Collie Pit Lakes; MiWER/Centre for Ecosystem Management Report 2010-11; Edith Cowan University: Perth, Australia, 2010.

72. Hrdinka, T. Typology and Potential Utilization of Anthropogenic Lakes in Mining Pits in the Czech Republic. Limnol. Rev. 2007, 7, 47-53.

73. Schultze, M.; Rinke, K.; Brode, E.; Benthaus, F.-C. Wasserqualität in Als Speicher Genutzten Tagebauseen. WASSERWIRTSCHAFT 2019, 109, 38-41. [CrossRef]

74. Verburg, R.; Bezuidenhout, N.; Chatwin, T.; Ferguson, K. The Global Acid Rock Drainage Guide (Gard Guide). Mine Water Environ. 2009, 28, 305-310. [CrossRef]

75. MEM. Guidelines for Metal Leaching and Acid Rock Drainage at Minesites in British Columbia; MEM (B.C. Ministry of Energy and Mines): Victoria, BC, Canada, 1998.

76. Fritz, W.; Tropp, P.; Meltzer, A. A Remediation and Reclamation Strategy for Disused Brown Coal Mines in the Geiseltal Area. Surf. Min. Braunkohle Other Miner. 2001, 53, 155-166.

77. Reichel, M.; Uhlig, G.; Schroeter, A.; Wilsnack, T. Natürlicher Rückhalt Und Abbau Deponiebürtiger Schadstoffe Am Beispiel Der Submersen Deponie Großkayna (Runstedter See). In Tagungsband Magdeburger Gewässerschutzseminar; Povodi Ohre: Chomutov, Czech Republic, 2010. 
78. MacKinnon, M.; Boerger, H. Description of Two Treatment Methods for Detoxifying Oil Sands Tailings Pond Water. Water Qual. Res. J. 1986, 21, 496-512. [CrossRef]

79. Johnson, E.; Miyanishi, K. Creating New Landscapes and Ecosystems. Ann. N. Y. Acad. Sci. 2008, 1134, 120-145. [CrossRef]

80. Vandenberg, J. Current Perspectives in Pit Lake Water Management and Passive Treatment. In Proceedings of the COSIA AI-EES Water Conference Workshop, Calgary, AB, Canada, 22-23 March 2016.

81. Han, X.; MacKinnon, M.D.; Martin, J.W. Estimating the in Situ Biodegradation of Naphthenic Acids in Oil Sands Process Waters by Hplc/Hrms. Chemosphere 2009, 76, 63-70. [CrossRef]

82. Marentette, J.R.; Frank, R.A.; Bartlett, A.J.; Gillis, P.L.; Hewitt, L.M.; Peru, K.M.; Headley, J.V.; Brunswick, P.; Shang, D.; Parrott, J.L. Toxicity of Naphthenic Acid Fraction Components Extracted from Fresh and Aged Oil Sands Process-Affected Waters, and Commercial Naphthenic Acid Mixtures, to Fathead Minnow (Pimephales Promelas) Embryos. Aquat. Toxicol. 2015, 164, 108-117. [CrossRef] [PubMed]

83. Lawrence, G.A.; Tedford, E.W.; Pieters, R. Suspended Solids in an End Pit Lake: Potential Mixing Mechanisms. Can. J. Civil Eng. 2016, 43, 211-217. [CrossRef]

84. Lu, M. Aqueous Geochemistry of Pit Lakes-Two Cases Studies at Rävlidmyran and Udden, Sweden. Ph.D. Thesis, Luleå University of Technology, Luleå, Sweden, 2004.

85. McCullough, C.D.; Vandenberg, J.A. Studying Mine Pit Lake Systems across Multiple Scales. Mine Water Environ. 2020, in press.

86. Morgenstern, N.R.; Vick, S.G.; Van Zyl, D. Independent Expert Engineering Investigation and Review Panel: Report on Mount Polley Tailings Storage Facility Breach. 30 January 2015. Available online: http://www.rosemontminetruth.com/wp-content/uploads/2015/ 02/ReportonMountPolleyTailingsStorageFacilityBreach.pdf (accessed on 20 January 2020).

87. Vandenberg, J.; Litke, S. Beneficial Use of Springer Pit Lake at Mount Polley Mine. Mine Water Environ. 2017, 37, 663-672. [CrossRef]

88. Beddoes, P.; Herrell, M.; Vandenberg, J.A.; Richards, J.; Millar, R.; McMahen, K. Validation of Springer Pit Lake Water Balance and Water Quality Model, Mount Polley Mine, British Columbia, Canada. In Proceedings of the IMWA Conference, Freiberg, Germany, 11-15 July 2016.

89. Jones, H.; McCullough, C.D. Regulator Guidance and Legislation Relevant to Pit Lakes. In Mine Pit Lakes: Closure and Management; McCullough, C.D., Ed.; Australian Centre for Geomechanics: Perth, Australia, 2011; pp. 137-152.

90. McCullough, C.D. Mine Water Research: Enhancing Mining Industry and Academic Collaboration. Mine Water Environ. 2016, 35, 113-118. [CrossRef]

91. Halír, J.; Žižka, L. Sandpit Lakes in the Tebo Basin Biosphere Reserve (Czech Republic). In Proceedings of the 10th International Mine Water Association (IMWA) Congress, Karlovy Vary, Czech Republic, 2-5 June 2008.

92. Stephens, F.J.; Ingram, M. Two Cases of Fish Mortality in Low Ph, Aluminium Rich Water. J. Fish Dis. 2006, 29, 765-770. [CrossRef]

93. Cech, M.; Peterka, J.; Riha, M.; Juza, T.; Kubecka, J. Distribution of Egg Strands of Perch (Perca fluviatilis L.) with Respect to Depth and Spawning Substrate. Hydrobiologia 2009, 630, 105-114. [CrossRef]

94. Svoboda, I.; Vrbova, I.; Ondráček, V. Surface Coal Mining and Land Reclamation in the Czech Republic. Górnictwo i Geoinżynieria 2007, 31, 587-594.

95. Otchere, F.A.; Veiga, M.M.; Hinton, J.J.; Farias, R.A.; Hamaguchi, R. Transforming Open Mining Pits into Fish Farms: Moving Towards Sustainability. Nat. Resour. Forum 2004, 28, 216. [CrossRef]

96. Vandenberg, J.; Lauzon, N.; Prakash, S.; Salzsauler, K. Use of Water Quality Models for Design and Evaluation of Pit Lakes. In Mine Pit Lakes: Closure and Management; McCullough, C.D., Ed.; Australian Centre for Geomechanics: Perth, Australia, 2011; pp. 63-80.

97. Canadian North Environmental Services. Giant Mine Human Health and Ecological Risk Assessment; Canadian North Environmental Services: Edmonton, AB, Canada, 2017.

98. Vandenberg, J.A.; McCullough, C.D.; Castendyk, D. Key Issues in Mine Closure Planning Related to Pit Lakes. In Proceedings of the joint International Conference on Acid Rock Drainage ICARD/International Mine Water Association (IMWA) Congress, Santiago, Chile, 21-24 April 2015.

99. McCullough, C.D.; Harvey, B.; Unger, C.J.; Winchester, S.; Coetzee, J. From Start to Finish-A Perspective on Improving Sustainable Development Aspects on Life-of-Mine Practices. In From Start to Finish: Life of Mine Perspective; AusIMM: Brisbane, Australia, 2018; pp. 395-400. 
100. McNeill, S.A.; Arens, C.J.; Hogan, N.S.; Köllner, B.; van den Heuvel, M.R. Immunological Impacts of Oil Sands-Affected Waters on Rainbow Trout Evaluated Using an in Situ Exposure. Ecotoxicol. Environ. Saf. 2012, 84, 254-261. [CrossRef]

101. Luek, A.; Rowan, D.J.; Rasmussen, J.B. N-P Fertilization Stimulates Anaerobic Selenium Reduction in an End-Pit Lake. Sci. Rep. 2017, 7, 10502. [CrossRef] [PubMed]

102. McCullough, C.D.; Lund, M.A. Limiting Factors for Crayfish and Finfish in Acidic Coal Pit Lakes. In Proceedings of the International Mine Water Conference (IMWA) Congress, Aachen, Germany, 19-23 October 2011.

103. Evans, L.; Cronin, D.; Doupé, R.G.; Hunt, D.; Lymbery, A.J.; McCullough, C.D.; Tsvetnenko, Y. Potential of Pit Lakes as a Positive Post-Mining Option-Examples, Issues and Opportunities; Centre for Sustainable Mine Lakes: Perth, Australia, 2005.

104. Noller, B.N.; Ng, J.C.; Matanitobua, V.; Harris, H.H.; Zheng, J.; Huynh, T. Assessment of Ecotoxicology and Health Risk from Bioaccumulation in Fish of Heavy Metals and Metalloids from Historical Mine Practices in the Leichhardt River, Queensland, Australia. In Proceedings of the Life of Mine, Brisbane, Australia, 28-30 September 2016.

105. D'Souza, G.; Miller, D.; Semmens, K.; Smith, D. Mine Water Aquaculture as an Economic Development Strategy. J. Appl. Aquac. 2004, 15, 159-172. [CrossRef]

106. Lienhoop, N.; Messner, F. The Economic Value of Allocating Water to Post-Mining Lakes in East Germany. Water Resour. Manag. 2009, 23, 965-980. [CrossRef]

107. Lienhoop, N.; Messner, F. The Economics of Mine Pit Restoration: The Case of Pit Lakes in Lusatia, Germany. In Acidic Pit Lakes_Legacies of Surface Mining on Coal and Metal Ores; Geller, W., Schultze, M., Kleinmann, R.L.P., Wolkersdorfer, C., Eds.; Springer: Berlin, Germany, 2013; pp. 421-435.

108. McCullough, C.D. Key Mine Closure Lessons Still to Be Learned. In Proceedings of the International Mine Closure 2016 Congress, Perth, Australia, 15-17 March 2016.

109. APEC. Mine Closure Checklist for Governments; Asia Pacific Economic Consortium (APEC): Toronto, ON, Canada, 2018.

110. ICMM. Integrated Mine Closure: Good Practice Guide, 2nd ed.; International Council on Mining and Metals (ICMM): London, UK, 2019.

111. Charette, T.; Wylynko, D. Generating Regional Guidance for Best Practice Pit Lake Closure and Reclamation. In Mine Pit Lakes: Closure and Management; McCullough, C.D., Ed.; Australian Centre for Geomechanics: Perth, Australia, 2011; pp. 43-52.

112. Swanson, S. What Type of Lake Do We Want? Stakeholder Engagement in Planning for Beneficial End Uses of Pit Lakes. In Mine Pit Lakes: Closure and Management; McCullough, C.D., Ed.; Australian Centre for Geomechanics: Perth, Australia, 2011; pp. 29-42.

113. Swanson, S.; Abbott, R.; Funk, W.; Kirk, L.; McKenna, G.; Ohlendorf, H.; Sandy, T. Building Stakeholder Engagement in Sustainable Solutions-The Strategic Advisory Panel on Selenium Management. In Proceedings of the Sixth International Conference on Mine Closure, Lake Louise, AB, Canada, 18-21 September 2011.

114. Nelson, J.; Scoble, M. Social License to Operate Mines: Issues of Situational Analysis and Process. In Proceedings of the Mine Planning and Equipment Selection (MPES) Conference, Banff, AB, Canada, 31 October-3 November 2005.

115. Schultze, M.; Geller, W.; Benthaus, F.C.; Jolas, P. Filling and Management of Pit Lakes with Diverted River Water and with Mine Water-German Experiences. In Mine Pit Lakes: Closure and Management; McCullough, C.D., Ed.; Australian Centre for Geomechanics: Perth, Australia, 2011; pp. 107-120.

116. Schultze, M.; Pokrandt, K.-H.; Scholz, E.; Jolas, P. Use of Mine Water for Filling and Remediation of Pit Lakes. In Proceedings of the International Mine Water Association (IMWA) Congress, Aachen, Germany, 4-11 September 2011.

117. Pelletier, C.A.; Wen, M.; Poling, G.W. Flooding Pit Lakes with Surface Water. In Mine Pit Lakes: Characteristics, Predictive Modeling, and Sustainability; Castendyk, D.N., Eary, L.E., Eds.; Society for Mining, Metallurgy, and Exploration (SME): Englewood, CO, USA, 2009; pp. 187-202.

118. McCullough, C.D.; Schultze, M. Engineered River Flow-through to Improve Mine Pit Lake and River Water Values. Sci. Total Environ. 2018, 640, 217-231. [CrossRef] 
119. Kulczyk, S.; Woźniak, E.; Derek, M. Landscape, Facilities and Visitors: An Integrated Model of Recreational Ecosystem Services. Ecosyst. Serv. 2018, 31, 491-501. [CrossRef]

120. Nürnberg, G.K. Assessing Internal Phosphorus Load-Problems to Be Solved. Lake Reserv. Manag. 2009, 25, 419-432. [CrossRef]

(c)

(C) 2020 by the authors. Licensee MDPI, Basel, Switzerland. This article is an open access article distributed under the terms and conditions of the Creative Commons Attribution (CC BY) license (http://creativecommons.org/licenses/by/4.0/). 